УДК 339.92

DOI: https://doi.org/10.37320/2415-3583/7.14

Корогодова О.O.

кандидат економічних наук, доцент кафедри міжнародної економіки, Національний технічний університет Украйни «Київський політехнічний інститут імені Ігоря Сікорського»

Моісеснко Т.Є. кандидат економічних наук, доцент кафедри міжнародної економіки, Наиіональний технічний університет Украйни «Київський політехнічний інститут імені Ігоря Сікорського»

\title{
ПРИНЦИПИ ФУНКЦІОНУВАННЯ СКЛАДНИХ УПРАВЛІНСЬКИХ СИСТЕМ НА ПРИКЛАДІ ТРАНСНАЦІОНАЛЬНИХ КОМПАНІЙ В УМОВАХ ЦИРКУЛЯРНОЇ ЕКОНОМІКИ НА ЗАСАДАХ ІНДУСТРІЇ 4.0
}

У статті досліджено проблематику світових соціально-економічних перетворень у період становлення Індустрії 4.0. Висвітлено основні тенденції в процесі транснаціоналізації сучасного бізнесу на засадах ииркулярної економіки. Зазначено актуальність дослідження інноваційних структур транснаціонального типу підприємниитва щодо переходу до ичркулярного типу здійснення економічних прочесів, що передбачає глобальний та регіональний ефект. Визначено иілі дослідження, якими є висвітлення прочесу адаптації складних управлінських систем до вимог Індустрії 4.0; формування приниипових змін діяльності ТНК на засадах ичиркулярної економіки; визначення принципів функціонування транснаціональних структур в умовах ииркулярної економіки на засадах Індустрії 4.0; пропозиції регулювання процесів трансферу капіталів в умовах зміни виробничоі парадигми. Висвітлено процес масового впровадження фізичних кіберсистем у фази суспільного виробництва. Наведено особливості ичиркулярної економіки, щчо полягають у трансформації виробничої та невиробничої сфер у єдиний простір. Зазначено, щзо проблемами, які виникають під час формування структури складних систем, є виокремлення структурних елементів (підрозділів) та встановлення взаємозв'язків між структурними елементами відповідно до умов функиіонування, цілей та системи мотивації. Візуалізовано основні елементи системи та їхній взаємозв 'язок в умовах впливу компонентів Індустрії 4.0. Перелічено вхідні та вихідні параметри функціонування системи управління транснаціональними структурами в контексті цииркулярної економіки. Наведено основні проблеми економічного змісту, з якими стикаються транснаціональні корпораціі у краӥнах, що розвиваються. Охарактеризовано процес перенесення аналітичних центрів у крайни, щзо розвиваються, наслідком чого є інтернаціоналізачія науково-дослідних заходів в умовах Індустрії 4.0. Наведено перелік структур транснаціонального типу підприємництва, які мають економічні інтереси у створенні бізнес-моделей ициркулярного типу, щзо підкреслює їх прагнення до стійкості інноваційного розвитку. Має інтерес методика формування принципів функціонування структур транснаціонального типу підприємництва в умовах Індустрії 4.0 на засадах изиккулярної економіки.

Ключові слова: бізнес-процеси, складні управлінські системи, ичикулярна економіка, Індустрія 4.0, транснаичінальні корпорації.

Постановка проблеми. Формування інноваційної парадигми економіки в епоху становлення Індустрії 4.0 передбачає застосування синергетичного ефекту від реалізації пізнавальної та практичної функцій економічної теорії. Традиційне припущення про дилему обмеженості ресурсів та безмежного зростання потреб набуває нової актуальності.

Перехід до циркулярної економіки в умовах транснаціоналізації передбачає підвищення якості функціонування складних управлінських систем, забезпечує їх сталий розвиток, а також створення нових ринкових ніш та інноваційних бізнесмоделей. Реалізація концепції сталого розвитку «виробництво - розподіл - обмін - споживання» набуває нових можливостей в умовах переходу до впровадження досягнень Індустрії 4.0.
Компанії транснаціонального типу підприємництва як представники глобальної бізнес-спільноти, яким належить провідна роль у визначенні та встановленні інноваційних напрямів розвитку окремих галузей і світової економіки загалом, уже мають економічні інтереси у створенні зазначених бізнес-моделей, що підкреслює їх прагнення до стійкості. Така стратегія чітко прослідковується у функціонуванні відомих корпорацій, таких як "B\&Q Limited", "BT Group", "Groupe Renault", "Cisco Systems", "National Grid", "Royal Philips Electronics", "Toyota Motor Corporation", "Veolia Environnement", підтверджуючи актуальність запропонованого дослідження.

Вирішення питань переходу до циркулярного типу здійснення економічних процесів передбачає глобальний та регіональний ефект. Отже, 
для України як країни, що багата на сировинні ресурси, зазначений напрям також займає центральні позиції сфери іiі інтересів у векторі розвитку та постійного вдосконалення.

Досягнення якісно нового рівня ресурсної ефективності, розумної спеціалізації, використання наявних ресурсів, оминаючи ефект негативного впливу на довкілля, передбачає застосування радикальних технологічних та структурних інновацій, адаптацію шаблонів підприємницької поведінки до умов циркулярної економіки, реалізацію масштабних інвестиційних проєктів як державного, так і приватного характеру.

Аналіз останніх досліджень i публікацій. Необхідність переорієнтації в бік економіки циркулярного типу є не лише припущенням, але й обгрунтованою необхідністю, що знаходить своє відображення у роботах науковців [1-4], а також у регіональній політиці урядів.

Більшість досліджень, присвячених циркулярній економіці, які проведені на цей час, зосереджена перш за все на бізнес-моделі підвищення ефективності використання ресурсів [3-5]. Теоретичні та практичні аспекти проблематики впровадження досягнень Індустрії $4.0 €$ об’єктом досліджень низки вітчизняних і зарубіжних науковців $[3 ; 4 ; 6]$. Сутність формування складних управлінських систем на прикладі транснаціональних структур докладно розглядається у джерелі [8]. Однак окремі аспекти мають бути зведені в систему принципів функціонування складних управлінських систем у вигляді ТНК в умовах циркулярної економіки на засадах Індустрії 4.0.

Мета статті полягає у визначенні новітніх ключових особливостей процесу адаптації складних управлінських систем до вимог Індустрії 4.0 та формуванні принципових змін їхньої діяльності на засадах циркулярної економіки. Увагу акцентовано також на пропозиціях щодо урядових заходів регулювання процесів трансферу капіталів в умовах зміни виробничої парадигми.

Виклад основного матеріалу. Хоча Україна не $\epsilon$ країною базування для власних транснаціональних компаній, проте на її території зосереджено значну кількість світових корпорацій (наприклад, "Bayer", "Coca-Cola", "Danone", "Henkel", "Procter \& Gamble", "Samsung", "Toyota", "Nestle"). 3 огляду на принципи циркулярної економіки уряду України варто не лише звернути увагу на підвищення рівня власної привабливості для світових ТНК, але й контролювати якість намірів тих корпорацій, що функціонують або планують організовувати діяльність на території нашої держави.

Водночас ринкова ситуація сьогодні свідчить про протилежні тенденції. У 2018 р. Україна наростила обсяги імпорту та експорту, проте темпи зростання імпорту вищі за темпи зростання експорту. Більша частина експортної продукції представлена сировиною, корисними копалинами та продуктами, для яких характерний низький ступінь переробки, зокрема в структурі експорту за 2018 р. переважали продовольчі товари та сільгосппродукція (41\%) [7].

Великі корпорації розглядають Україну як сировинну країну та джерело ресурсів, не ставлячи у пріоритет розвиток переробної промисловості та створення готової продукції на експорт. Незначна кількість транснаціональних компаній розміщує свою діяльність на території України задля виробництва продукції на експорт. Таким чином, більшість зареєстрованих в Україні корпорацій транснаціонального типу складають компанії $з$ досить швидким обігом капіталу.

3 огляду на зазначені дані та принципи циркулярної економіки варто дотримуватись стратегії залучення продуктивного іноземного капіталу компаній, які мають на меті дбайливе використання ресурсів, створення можливостей для ресурсного відтворення, привнесення нових технологій, розширення та формування виробничих потужностей для виробництва товарів.

Перспективним напрямом економічної діяльності має стати контроль якості діяльності тих ТНК, що здійснюють або планують здійснювати свою комерційну й виробничу діяльність в Україні. Зазначені принципи мають знаходити своє відображення не лише у стратегічному баченні, але й у системі управління. Отже, розглянемо складні системи, що стосуються процесу здійснення підприємницької діяльності на міжнародному рівні.

Кожна система наділена певними функціями, реалізація яких $є$ можливою за наявності взаємозв'язків між елементами цієї системи та взаємодії між ними. Системи поділяються на закриті, що функціонують ізольовано (чи незалежно) від зовнішнього середовища, й відкриті, які певною мірою зазнають зовнішнього впливу [8]. Управління відзначають як функцію системи, що забезпечує організацію цілеспрямованої діяльності системи, що керується. Слід зазначити, що в умовах Індустрії 4.0 відбувається масове впровадження фізичних кіберсистем у процес «виробництво - розподіл - обмін - споживання». Особливістю, що властива циркулярним принципам, в цьому разі $є$ поступове розмивання відмінностей між виробничою та невиробничою сферами завдяки вбудованим елементам сервісної економіки в процес користування матеріальними об' єктами.

Проблемами, що виникають під час формування структури складних систем, $\epsilon$ виокремлення структурних елементів (підрозділів) та встановлення взаємозв'язків між структурними елементами відповідно до умов функціонування, цілей та системи мотивації. Крім того, варто враховувати те, що у сучасному підприємницькому сере- 
довищі всі структурні елементи функціонують під впливом зовнішніх та внутрішніх факторів, які для транснаціональних корпорацій, що прагнуть до розвитку своєї діяльності, формуються відповідно до впливу компонентів Індустрії 4.0 (рис. 1).

Елемент, яким керують, є сукупністю компонентів, що сприяють основному процесу (підрозділ, цех, технологічний процес). До вхідних параметрів, що діють на елемент, яким керують, можна віднести попит на продукцію та послуги, час виконання замовлень, законодавчі обмеження тощо [8]. Вихідними параметрами функціонування системи (в нашому разі - ТНК) $е$ обсяги продукції та послуг, фінансові показники діяльності, політичний вплив тощо. Функціонування системи можна описати внутрішнім станом, який характеризується чисельністю країн, де розміщені підрозділи ТНК, загальною кількістю робітників, обсягами виробництва, рівнем якості виготовленої продукції та наданих послуг, виробничими потужностями тощо. Динамічними умовами, в яких відбуваються передача й прийом інформації, $є$ мережева інтеграція, інте- лектуальні технології та роботизація. Мережева інтеграція забезпечує зв' язок між окремими вузлами мережі й покращує доступ до інформації; інтелектуальні технології автоматично відстежують майбутні події та надають інформацію для прийняття рішень [9]; роботизація та коботизація поглиблюють процес автоматизації та забезпечують дистанційне управління.

Зазначимо, що зростання ролі інновацій в діяльності ТНК та їхнього впливу на розвиток емерджентних економік спричиняє поступовий перехід від розроблення в країнах базування 3 подальшим масштабуванням наукових досліджень у країни перебування до вихідного заснування аналітичних підрозділів у країнах, що розвиваються. Ще однією тенденцією розвитку структур транснаціонального типу підприємництва $є$ розміщення аналітичних центрів у безпосередній близькості до крупних закладів вищої освіти, тобто лідерів рейтингів.

Зміна внутрішнього стану керованої підсистеми здійснюється за допомогою прийняття та виконання управлінських рішень. Ці рішення

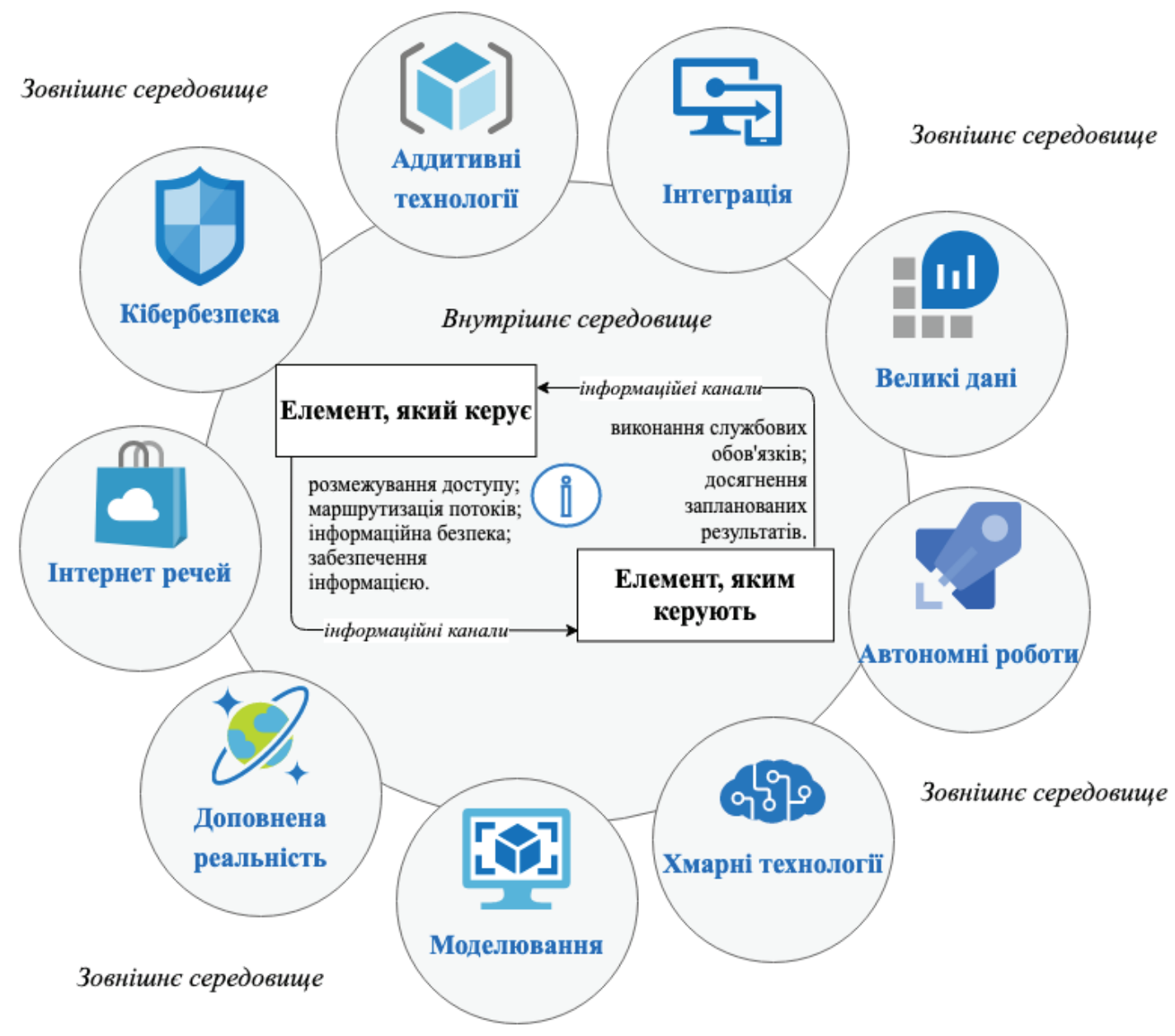

Рисунок 1 - Основні елементи системи та їх взаємозв'язок в умовах впливу компонентів Індустрії 4.0 
можуть прийматися під час перегляду цілей функціонування системи, зміни характеристик зовнішнього середовища.

Декаплінг як сукупність економічних процесів та явищ корінним чином змінює цілі функціонування всієї системи. Функціонування транснаціональних компаній, що дотримуються принципів циркулярної економіки, спричиняє значний вплив на здатність економічної системи суспільства зростати без відповідного збільшення використання енергії та ресурсів (межі джерел), а також екологічного навантаження (межі поглинання).

Властивості будь-якої системи впливають на формування структури вищезазначених підсистем. Проте структура кожної з цих підсистем обумовлюється особливостями галузі, напряму діяльності, технологічними процесами, що використовуються транснаціональними компаніями. При цьому під структурою підсистеми розуміють iii склад 3 компонентів, що мають між собою відповідні взаємозв'язки, що визначаються поставленими перед системою задачами та виконуваними функціями.

Існують певні проблеми, що виникають під час формування структури складних систем, зокрема виокремлення структурних елементів (як правило, це філії, дочірні та асоційовані компаніï); встановлення взаємозв'язків між структурними елементами відповідно до умов функціонування, цілей та системи мотивації. Вирішення зазначених проблем безпосередньо пов'язане 3 процесами перетворення матерії, енергії та інформації.

Зазначимо, що для кожної підсистеми обсяги необхідних перетворень різняться. Так, для керуючої підсистеми значна частка ресурсів спрямовується на перетворення інформаціі, а саме отримання даних, їхню обробку, передачу на інші підсистеми як керуючі дії. Для керованої підсистеми характерним є перетворення матерії та енергіï, тобто здебільшого цим є виробничі процеси в підрозділах.

У межах загальної структури організаційної системи ТНК виокремлюються три елементи, такі як виробнича структура чи структура надання послуг, апарат управління, інформаційна структура.

Для нормального функціонування керуючої підсистеми необхідні такі складові, як канали та методи вимірювання вихідних параметрів і стану складових частин задля отримання відповідної інформації; блок керування (апарат управління), де відбувається порівняння отриманих під час вимірювання результатів із запланованими цілями (еталоном) і який керує механізмами корекції відповідно до потреб системи; канали управління й механізми корекції [8].

Надійність системи управління організацією підвищується за використання постійної корекції на основі аналізу потоку інформації зворот- ного зв'язку. За відхиленнях значень фактичних результатів функціонування систем від запланованих понад допустимого рівня $є$ можливим виникнення ситуації, яка називається втратою керованості. Це означає, що за таких параметрів системи та навколишнього середовища їі цілі не можуть бути досягнутими. Результатом такого стану можуть бути такі варіанти перетворення системи, як крах системи та припинення і1і існування; зміна цілей системи за незмінної структури; зміна конфігурації системи для досягнення поставлених цілей. Реалізація тієї чи іншої організації структури управління в компанії, ii рівень складності мають відповідати місії та цілям організації та тим функціям, що забезпечує керуюча підсистема [8].

Для транснаціональних компаній структура системи управління має враховувати специфіку предметів та засобів праці, що використовуються конкретними підрозділами. Кожна цілеспрямована система містить замкнені петлі керування та в будь-який момент часу має контролювати показники ступеня досягнення цієї цілі.

Обсяги управлінської діяльності залежать від розміру організації та різноманітності сфер ii функціонування. Як правило, невеликі за розмірами компанії можуть входити до структури транснаціональних компаній, технологічно вони забезпечують діяльність крупних корпоративних структур з певного напряму чи є посередниками під час здійснення технологічного ланцюга в процесі виготовлення продукції чи надання послуг. Управлінська діяльність в офісі материнської компанії пов'язана зі значними витратами розумової та фізичної праці, а також високим рівнем організації системи управління, адже кількість підрозділів може сягати десятків, сотень чи тисяч одиниць у багатьох країнах світу.

Система управління ТНК досить складна, не лише зорієнтована на побудову зручної, ефективної та універсальної моделі в межах корпорації, але й передбачає відображення динамічного руху, постійне вдосконалення бізнес-процесів. Поштовхом до постійного перегляду та вдосконалення бізнес-процесів $\epsilon$ не лише бажання корпорації отримувати додаткові прибутки за рахунок оптимального використання наявних ресурсів (наприклад, застосування принципів Lean-management) [5], але й необхідність демонструвати світовому співтовариству свідоме ставлення до природних ресурсів та стану навколишнього середовища (наприклад, шляхом використання міжнародних стандартів якості ISO, запровадження системи екологічного менеджменту).

Нагадаємо, що, незважаючи на високий рівень фінансової та технічної потужності, діяльність ТНК більшою мірою зосереджена на експлуатації природних і людських ресурсів. Часто вони не 
ставлять за пріоритет збереження та відновлення ресурсів, керуючись більшою мірою рівнем очікуваних прибутків. Обсяги впливу ТНК на забруднення довкілля змушують міжнародне співтовариство шукати форми обмеження й запобігання ïх негативного впливу. Одним з перспективних та дієвих засобів стає серія міжнародних добровільних колективних договорів і стандартів, які розроблені з ініціативи та за участю громадськості. Подібні добровільні угоди - це звична й використовувана форма для бізнесу незалежно від його сфери діяльності та обсягів компаній.

Зазначені документи містять зібраний по всьому світі досвід, пройшли перевірку часом $\mathrm{i}$ сприятимуть підвищенню рівня відповідальності бізнесу перед суспільством щодо збереження довкілля, ефективного й раціонального використання ресурсів, як максимум, їхнього збереження. Добровільна згода ТНК керуватись у своїй діяльності запропонованими угодами й стандартам $\epsilon$ також визнанням того, що внутрішня екологічна політика корпорацій сприятиме збільшенню їхніх доходів і підвищенню рівня конкурентоспроможності. Громадськість отримує додатковий ефективний інструмент контролю за діяльністю корпорацій, які прийняли зазначені зобов'язання.

До важливих корпоративних екологічних стандартів та угод можна віднести такі:

1) Коаліція за екологічно відповідальний бізнес (The Coalition for Environmentally Responsible Economies, CERES) [10];

2) Хартія ділових кіл за сталий розвиток Міжнародної торгової палати (International Chamber of Commerce's Business Charter for Sustainable Development) [11];

3) Схема управління та аудиту в області навколишнього середовища Європейського Союзу (European Union's Environmental Management and Audit Scheme, EMAS) [12];

4) Серія стандартів 14000 Міжнародної організації зі стандартизації (The International Organization for Standardization, ISO) [13].

Інтерес до зазначених документів з боку корпорацій постійно збільшується, про що свідчить постійно зростаюча кількість отриманих сертифікатів ISO 14001 та періодичність перегляду цих документів, розроблення та поширення нових удосконалених редакцій стандартів для користувачів по всьому світі.

Процеси глобалізації економіки певною мірою руйнують усталені уявлення про національну приналежність корпорацій, контроль за діяльністю яких з боку урядів постійно слабшає. ТНК функціонують у власному правовому полі, використовуючи недосконалість національного законодавства, міжнародних конвенцій та угод. Проте принципи циркулярної економіки поступово інтегруються у функціонування ТНК, надаючи нові дієві інструменти управління, оптимізації бізнеспроцесів, збереження ресурсів, а також забезпечуючи позитивну репутацію $з$ боку громадськості за рахунок дбайливого ставлення до використання ресурсів, пошуку шляхів їх відтворення замість їх знищення та зниження негативного впливу на природне середовище.

Таким чином, засадами функціонування складних управлінських систем на прикладі транснаціональних компаній в умовах циркулярної економіки на основі Індустрії $4.0 €$ :

- забезпечення єдності освітніх, наукових та практичних аспектів під час формування політики управління підрозділами транснаціональних корпорацій;

- орієнтація на синергетичний підхід у стратегічному плануванні діяльності ТНК з урахуванням ефекту декаплінгу;

- збалансованість досліджень процесів транснаціоналізації компаній, рівня інноваційного розвитку суспільства, бізнес-моделей циркулярного типу;

- орієнтація на залучення в Україну капіталу транснаціональних структур, що зацікавлені у створенні товарів 3 високою доданою вартістю в умовах заощадження та відновлення природних ресурсів;

- врахування транснаціональними компаніями тенденції згладжування відмінностей між виробничою та невиробничою сферами завдяки вбудованим елементам сервісної економіки в процес користування матеріальними об'єктами;

- поглиблення рівня впливу елементів зовнішнього середовища (адитивні технології, інтеграція, кібербезпека, великі дані, автономні роботи, Інтернет речей, доповнена реальність, моделювання) на діяльність складних управлінських систем;

- заснування аналітичних підрозділів транснаціональних корпорацій у країнах, що розвиваються, а також розміщення науково-дослідних центрів у безпосередній близькості до лідерів вищої освіти;

- ефективність інформаційного забезпечення бізнес-процесів корпорацій за умов використання досягнень Індустрії 4.0;

- підвищення рівня відповідальності транснаціональних компаній перед суспільством щодо оптимізації бізнес-процесів, орієнтованих на збереження навколишнього середовища, ефективного й раціонального використання ресурсів;

- моніторинг діяльності структур транснаціонального типу підприємництва урядами країн та наднаціональними утвореннями.

Висновки. На основі проведеного аналітичного дослідження визначено нові ключові особливості процесу адаптації складних управлінських систем (на прикладі підприємницьких структур 
транснаціонального типу) до вимог новітнього технологічного укладу, що знайшли своє відображення в програмі Індустрії 4.0.

Результати аналітичного огляду інформації щодо проблеми дають змогу виокремити особливості формування системи управління транснаціональними корпораціями під час адаптації їхньої діяльності до засад циркулярної економіки, а саме нові принципи функціонування складних управлінських систем.

На основі проведеного дослідження сформульовано концепцію про уявлення доцільності вжиття урядових заходів щодо регулювання процесів трансферу капіталів в умовах зміни виробничої парадигми 3 акцентом на залучення в економіку України продуктивного іноземного капіталу компаній, які мають на меті дбайливе використання ресурсів, створення можливостей для ресурсного відтворення, привнесення нових технологій, розширення та створення виробничих потужностей для виробництва товарів і послуг.

Сформульовано концепцію конкретних напрямів подальших досліджень, що полягають в удосконаленні запропонованих принципів та інтеграції їх у систему управління структурами корпоративного типу.

\section{Список використаних джерел:}

1. Voitko S. Conception of Industry 4.0 in the Sustainable Grown of Ukraine. Creative Business for Smart and Sustainable Crowth. CreBUS, 2019.

2. Шваб К. Четверта промислова революція. Формуючи четверту промислову революцію. Харків : КСД, 2019.416 с.

3. Kalmykova Yu., Sadagopan M., Rosado L. Circular economy: From review of theories and practices to development of implementation tools. Resources, Conservation and Recycling. 2018. Vol. 135. P. 190-201.

4. Війкман А., Сконберг К. Циркулярна економіка та переваги для суспільства. Явні переможці в області робочих місць та клімату в економіці, заснованій на відновлюваній енергії та ресурсоефективності. Звіт про дослідження на вимогу Римського клубу за підтримки Фонду MAVA. Ukrainian association The Club of Rome. URL: http:// www.clubofrome.org.ua/wp-content/uploads/2017/08/The-Circular-Economy-CoR_UA-2.pdf (дата звернення: 15.10.2019).

5. Biazzo S., Panizzolo R., de Crescenzo A.M. Lean Management and Product Innovation: A Critical Review. Understanding the Lean Enterprise. Measuring Operations Performance. Springer, Cham / A. Chiarini, P. Found, N. Rich (eds). 2016. P. $237-260$.

6. Hermann M., Pentek T., Otto B. Design Principles for Industry 4.0 Scenarios: A Literature Review. Working Paper. Technische Universität Dortmund. 2015. No. 1. 16 p.

7. Експорт товарів. Імпорт товарів / Державна служба статистики України. URL: http://www.ukrstat.gov.ua (дата звернення: 10.10.2019).

8. Войтко С., Гавриш О., Корогодова О., Моісеєнко Т. Транснаціональні корпорації : навчальний посібник. Київ : НТУУ «КПІ», 2016. 208 с.

9. Четвертая промышленная революция. Целевые ориентиры развития промышленных технологий и инноваций. Світовий економічний форум. URL: http://www.weforum.org (дата звернення: 21.10.2019).

10. Коаліція за екологічно відповідальний бізнес. The Global Development Research Center. URL: http://www.gdrc.org/sustbiz/ceres-principles.html (дата звернення: 01.10.2019).

11. Хартія ділових кіл за сталий розвиток Міжнародної торгової палати. International institute of sustainable development. URL: https://www.iisd.org/business/tools/principles_icc.aspx (дата звернення: 11.10.2019).

12. Wenk M.S. The European Union's Eco-Management and Āudit Scheme (EMAS). Springer. 2005. 217 p.

13. Серія стандартів 14000 Міжнародної організації зі стандартизації. International Organization for Standardization. URL: https://www.iso.org/iso-14001-environmental-management.html (дата звернення: 05.10.2019).

\section{References:}

1. Voitko S. (2019), "Conception of Industry 4.0 in the Sustainable Grown of Ukraine”. Creative Business for Smart and Sustainable Crowth, CreBUS.

2. Schwab K. (2019), "Chetverta promyslova revoliutsiia. Formuiuchy chetvertu promyslovu revoliutsiiu". [The fourth industrial Revolution. Forming the fourth industrial Revolution]. FLC, Kharkiv, Ukraine.

3. Kalmykova Yu., Sadagopan M., Rosado L. (2018), "Circular economy: From review of theories and practices to development of implementation tools". Resources, Conservation and Recycling, vol. 135, pp. 190-201.

4. The official site of the Ukrainian association The Club of Rome (2019), "Tsyrkuliarna ekonomika ta perevahy dlia suspil'stva. Yavni peremozhtsi v oblasti robochykh mists' ta klimatu v ekonomitsi, zasnovanij na vidnovliuvanij enerhii ta resursoefektyvnosti. Zvit pro doslidzhennia na vymohu Ryms'koho klubu za pidtrymky Fondu MAVA”. [Circular Economics and benefits for society. Obvious winners in the field of workplace and climate in the economy, based on renewable energy and resource efficiency. Report on the study on demand of the Rome Club with the support of MAVA Foundation], available at: http://www.clubofrome.org.ua/wp-content/uploads/2017/08/The-Circular-Economy-CoR_UA-2.pdf (accessed: 15 October 2019).

5. Biazzo S., Panizzolo R., de Crescenzo A.M. (2016), “Lean Management and Product Innovation: A Critical Review”. Understanding the Lean Enterprise. Measuring Operations Performance. Springer, Cham, pp. 237-260.

6. Hermann M., Pentek T., Otto B. (2015), "Design Principles for Industrie 4.0 Scenarios: A Literature Review". Working Paper. Technische Universität Dortmund, vol. 1, 16 p.

7. The official site of the State Statistics Service of Ukraine. (2019), "Export of goods. Import of goods", available at: http://www.ukrstat.gov.ua (accessed: 10 October 2019). 
8. Voitko S., Gavrysh O., Korohodova O., Moiseienko T. (2016), Transnatsional'ni korporatsii : navchal'nyj posibnyk [Transnational corporation : educ. tutorial]. NTUU “KPI”, Kyiv, Ukraine.

9. The official site of the World Economic Forum. (2019), "The Fourth Industrial Revolution. Targets for industrial technology and innovation", available at: http://www.weforum.org (accessed: 21 October 2019).

10. The official site of the Global Development Research Center. (2019), "The Coalition for Environmentally Responsible Economies", available at: http://www.gdrc.org/sustbiz/ceres-principles.html (accessed: 1 October 2019).

11. The official site of the International institute of sustainable development. (2019), "The International Chamber of Commerce's Business Charter for Sustainable Development”, available at: https://www.iisd.org/business/tools/principles_icc. aspx (accessed: 11 October 2019).

12. Wenk M.S. (2005), “The European Union’s Eco-Management and Audit Scheme (EMAS)”. Springer, 217 p.

13. The official site of the International Organization for Standardization. (2019), "The Standards Series 14000 of The International Organization for Standardization", available at: https://www.iso.org/iso-14001-environmental-management.html (accessed: 5 October 2019).

Korohodova Olena, Moiseienko Tetiana National Technical University of Ukraine "Igor Sikorsky Kyiv Polytechnic Institute"

\section{PRINCIPLES OF CONTROLLING COMPLEX SYSTEMS IN CIRCULAR ECONOMY (ON THE TRANSNATIONAL CORPORATIONS EXAMPLE) IN THE CONDITIONS OF INDUSTRY 4.0}

The problems of the world socio-economic transformations during the establishment of Industry 4.0 are investigated in this article. The main tendencies in the process of transnationalization of modern business on the basis of circular economy are lighted. The relevance of the research of innovative transnational structures in terms of transition to circular type of economic processes, which implies global and regional effect, is indicated. The research targets are defined: 1) coverage of the adaptation process of complex management systems to Industry 4.0 requirements; 2) formation of fundamental changes in the TNC's activities on the principles of circular economy; 3) defining the principles of transnational structures function in the conditions of circular economy on the Industry 4.0 basis; 4) formations of proposals for regulating of capital transfer processes in terms of changing the industrial paradigm. The mass implementation process of physical cyber systems in production phases is lighted. The features of circular economy, which consists in the transformation of production and non-production sphere into a single space, are characterized. The problems of formation of the structure of complex systems are defined. Basic elements of the system and their interrelation in the conditions of influence of Industry 4.0 components are visualized. The input and output parameters of the system of management of transnational structures in the context of circular economy are lighted. The main problems of economic content faced by transnational corporations in developing countries are presented. The process of migration of think tanks to developing countries, which resulted in the internationalization of the scientific and research activities in the Industry 4.0, is characterized. A list of structures of transnational type of entrepreneurship, which have economic interests in creating business models of circular type, emphasizes their aspiration to innovative development sustainability. The method of principles formation of transnational type of entrepreneurship functioning in the Industry 4.0 on the basis of circular economy is of interest.

Key words: business processes, complex systems, circular economy, Industry 4.0, transnational corporations.

JEL classification: F21, F23, O14, Q56. 